\title{
Between the Homeland and Diaspora: Identity Dilemma in Indian Literature
}

\author{
Indrani Atul Borgohain ${ }^{1}$, \& Deema Ammari ${ }^{2}$ \\ ${ }^{1}$ Ph.D. candidate, Department of English Language and Literature, University of Jordan, Jordan \\ ${ }^{2}$ Assistant Professor, Department of English Language and Literature, University of Jordan, Jordan \\ Correspondence: Indrani Atul Borgohain, Ph.D. candidate, Department of English Language and Literature, \\ University of Jordan, Jordan.
}

Received: January 17, 2022

Accepted: February 17, $2022 \quad$ Online Published: February 23, 2022

doi:10.5430/wjel.v12n1p221

URL: https://doi.org/10.5430/wjel.v12n1p221

\begin{abstract}
The article aims to analytically and comparatively examine how the negotiation of identity is represented in Indian literature, both in the homeland and abroad, in a situation where cultures meet, collide, and merge. The focus of the article will be on four books: Aravind Adiga's The White Tiger (2008), Bapsi Sidwa's Water (2006), Kiran Desai's The Inheritance of Loss (2006), and Bharathi Mukherjee's Jasmine (1989). All the authors write about identity from a particular cultural context: the Bengali community in the USA, Brahmins in the Indian caste system, the privileged and less-privileged status of Indian individuals, and the hegemonic aspirations of the middle class that have taken the form of politics and produce socio-cultural inequalities. Because of the complex social structure dominated by the Indian caste system, one aspect of migrant experiences is the limitations placed by society on their identity, which can also be a critical determinant of their economic well-being and thus affect identity formation. Accordingly, the presumption is that the utility of the protagonists, both the immigrants and the locals in their homeland, encompasses economic well-being and cultural identity. Despite their sense of alienation, displacement, and rootlessness, the protagonists in all the novels that I have mentioned above manage to carve out a space of belonging for themselves, be it in their homeland or abroad, despite social, political, and cultural obstacles.
\end{abstract}

Keywords: alienation, caste system, diaspora, dilemma, mimicry, subaltern

\section{Introduction}

This study examines identity dilemmas in Indian literature in the homeland and diasporas, as projected in Aravind Adiga's The White Tiger (2008), Kiran Desai's The Inheritance of Loss (2006), Bapsi Sidhwa's Water (2006), and Bharati Mukherjee's Jasmine (1989). Since the study is concerned with movement and alienation within and beyond the borders of the homeland, the careful selection of novels is not based on a specific time frame, but rather on different cultural and sociopolitical contexts of India.

The study argues for different levels of diaspora: one caused by the hierarchical caste struggle in the homeland leading to alienation, and the actual figures who move to the West. The characters who are in their homeland belong to ethnic minorities, live alongside the dominant culture, and struggle in its borderlands. As Ien Ang states, "The very name with which the 'ethnic' is referred to - Chinese [or Indian] - already transposes him or her to, and conjures up the received memory of, another site of symbolic belonging, a site which is not 'here"' (1994: 17). The idea is that these ethnic communities are a sign of lack, an affirmation that one belongs to 'another' homeland. They live in exile, are displaced from their homeland, and look forward to being part of that homeland. As Paul Gilroy argues in his article "Diaspora", the diaspora is not defined by biographical connections across geographical areas but is created by and through differentiation. Diaspora is based on conflicting feelings, on the ambivalence of belonging, especially that it is characterized by processes of exclusion (Gilroy, 1994). This legitimizes the notion that members of the lower Indian caste live in a constant state of diaspora, even within the borders of their country. Throughout their lives, the characters feel like outcasts from the social life of their hometown. Their stories illustrate a kind of alienation through which minorities are excluded from the Indian mainstream. Ultimately, they are doubly marginalized, both from the external and the internal agencies, both within their category and from the dominant category. However, the individuals who move to the West, become members of what this study calls a "double diaspora," a hybrid experience that transcends the boundaries of ethnicity and nationalism. This type of diaspora is characterized by Published by Sciedu Press 
multiple dualities as they are both Indian and American, with their homeland becoming their adopted homeland, and their new adopted homeland, America, exacerbating their alienation.

Dispersion, leaving one's hometown, and moving away from one's cultural context are among the most important themes of diaspora. In his article "Diasporas in Modern Societies: Myths of Homeland and Return," William Safran describes diaspora in the context of several groups: as dispersion from a center to two or more peripheral or foreign regions; as preservation of collective memory, vision, or myth. It also refers to the belief that full acceptance by the host country is not possible, leading to alienation and displacement (Safran, 1991). Diaspora thus evokes various contested ideas and images. It encompasses numerous blends of cultures, languages, histories, people, places, and times. It not only means that people are dispersed to different places, but also that they come together in other places, and form new communities. Brah, in Cartographies of Diaspora: Contesting Identities (1996) asserts that "experiences of diasporas are different, and all diasporas refer, in essence, to a certain kind of displacement" (183). In such circumstances, a new kind of culture and a new consciousness form to complement the remaining culture. Thus, new imagined communities emerge that do not simply replace the old ones but create a new community that we know as the "New Diaspora" according to Benedict Anderson (2006).

William Safran in "Diasporas in Modern Societies: Myths of Homeland and Return" (1991), argues that the meaning of diaspora today has a new perspective. More specifically, "diasporic communities" are used as metaphorical terms for different categories of people: Expatriates, refugees, foreign residents, ethnic and racial minorities; in much the same way as "ghettoization" has come to denote all kinds of constricted and deprived urban environments (Safran, 83). Diaspora also refers to populations, such as members of ethnic or religious groups who are originally from the same place but have settled in different places. Other characteristics of diaspora, according to Safran, include feelings of non-acceptance, alienation, or isolation.

The Indian diaspora, then, is a general term used to describe people who migrate either across the country's borders or across the states and territories that currently lie within the borders of the Republic of India. India is a country of twenty-nine states and seven union territories. People leave their familiar surroundings, cross states and territories, and experience what they perceive as foreignness, even though they are still within the borders of the same country. Therefore, foreignness is not limited to living in a country that is foreign to one's home country. It also includes feelings of alienation that one may experience within the borders of one's home country and between states in the same country. It refers to the movement of people from one state to another, as Madhu Tyagi notes in his book, Theory of Indian Diaspora: Dynamics of Global Migration (2017). In this sense, Aravind Adiga's novel The White Tiger exhibits diasporic features. The diasporic experience is evident in Balram, the protagonist, who describes his journey from his rural village to Delhi and then to the life of a successful entrepreneur in Bangalore. The diasporic experience is also evident in Water when Chuyia and the other widows from different regions and states are discarded to a widows' ashram, an institution for widows, where they must live the rest of their lives in penance. Cohen argues that "Diaspora signified a collective trauma, a banishment, where one dreamt of home but lived in exile" (1997a, ix). Diaspora, then, involves a concept of identity that discusses ethnic and cultural identities (Hall, 1990), because diaspora focuses on multinational and dynamic processes related to ethnic commonalities, that can acknowledge differences and diversity.

The Indian caste system plays an important role in the discrimination that leads people to marginalization and in between. Caste is a characteristic determined by birth, regardless of the beliefs the individual practices. It is a system of social stratification that divides Hindus into rigid, hierarchical groups. The caste system divides Hindus into four main categories. At the top of the hierarchy are the Brahmins, who are intellectuals. Rural communities are also divided into upper and lower castes. Brahmins do not accept food and drink from lower castes, and people marry only within their caste. Lower castes are denied many rights and are socially ostracized. They are not allowed to cross the boundary between their part of the village inhabited by the higher castes. Thus, the lower caste is completely excluded because of their lowest hierarchy in the caste system. A.L. Kroeber, in the Encyclopedia of the Social Sciences (1930), describes the caste system as a system of social stratification, which is an example of rank-based aggregations of people that are generally rigid, fixed from birth, and do not allow for individual mobility. The upper caste has a strong position in society and seeks to demonstrate its power to the lower caste. Due to the dominance of the caste and colonial system, these hegemonic influences have produced the privileged and less-privileged status of Indian individuals. Therefore, in India, socially constructed values are seen as the habit, culture, or norm of a particular society and are thus validated. Whatever the cause, the lower caste or the less privileged are victimized by signs of their status. They are treated degradingly because they are considered too "dirty" or "defiling" by the higher or upper caste communities, resulting in an identity dilemma. 
The diasporic element can be seen in Bapsi Sidhwa's Water and Aravind Adiga's The White Tiger, in which the loneliness of the characters is described. This loneliness is the result of external circumstances, the hegemonic caste system, and cultural hierarchy, which show their effects on the inner psyche of the characters. Balram, the downtrodden, is loathed by the privileged society; Chuyia, marginalized first as a woman and then as a widow during the Indian colonial period. They are alienated, displaced in their homeland. This is not only social discrimination but also a blot on humanity. First, they are defined by caste, and second, they are unholy or ostracized. So, they are doubly marginalized. There are so many widows like Chuyia and the lower class like Balram, who live scattered in India. They are called minorities in their home country, as Safran documents (1991). Gabriel Sheffer in Diaspora Politics: At Home Abroad (2003), has also used the term "diaspora" as "ethnonational diaspora" because these dispersed ethnic groups who reside permanently in host countries or nation-states (as in India) far from their homelands to preserve their distinctive identities engage in cultural, social, economic, and political struggles, and other dispersed groups of the same nation (10), and Chuyia and Balram fit into this category.

James Clifford describes diasporas as "dispersed networks of peoples who share common historical experiences of dispossession, displacement [and] adaptation" (Clifford, 309). Furthermore, Clifford describes "diaspora discourses" as "experiences of displacement, of constructing homes away from home, while remaining rooted in specific, discrete histories" (302). They struggle to survive and maintain their identities in a foreign land. In this context, Bharati Mukherjee's Jasmine and Kiran Desai's The Inheritance of Loss address diasporic discourses. Although the diasporic characters find themselves in the West, they remain rooted in their past. Both novels are linked to Indian-Western identities and deal with themes of immigration experiences, identities, and displacement. They are members of a double diaspora characterized by several dualities, such as being Indian, American, and British. Knott and Mcloughlin argue that the double diaspora illustrates how diasporic space is shaped by multiple homelands and contested relationships between people with different subjects (2010). More importantly, Werbner notes that the double diaspora appears "not as a homogeneous, unified, monolithic, harmonious form of sociality, but as heterogeneous and conflictual" (Werbner, 77). Both novels depict the protagonists' journey from India to a foreign country and are primarily concerned with internal conflicts in the context of the cultural shifts that leave them in exile and alienation.

In "Transnational Locality: Diasporas and Indentured South Asians" (2015), Movindri Reddy states that in some situations, the diaspora is often considered threatening to state security Movindri Reddy notes that diasporas are often seen as threats to state security in some situations. He argues that diasporas are insiders in the nation-state; at the same time, they are outsiders in all states. They reside in transnational places that are rooted but also distant. They have marked Indians, but are also alienated from other national ethnic groups (2). Guilt, nostalgia, displacement, alienation, double consciousness, and the quest for identity are some concepts associated with diasporic consciousness. It also involves issues related to a merging or dissolution of cultures, as Shilpa Goyal states in her article "The Saga of the Journey of Indian Diaspora" (2017). The White Tiger and Water are the sagas of the suffering of the protagonists - Balram and Chuyia. Their sufferings and agonies are not caused by fate, but by their fellow human beings and the social atmosphere, from which the sufferers still have high and persistent hopes for a better life. Their inner conflict and resistance illustrate that the Indian caste system is responsible for the construction of the categorized less privileged, reflecting their double consciousness. Du Bois explains that "Double consciousness" is a feeling of "two-ness," two souls, two thoughts, and the sense of always seeing oneself through the eyes of others $(1903,2)$. Furthermore, Du Bois claims that the duality of consciousness seems to indicate a fragmented psychic space, a volitional human activity that questions the self (Bois, 1996).

The Indian diaspora is transnational in the sense that it is characterized by cultural diversity, including religions, languages, and other forms of social stratification. There are diasporic communities that have formed based on linguistic or regional identities, such as Punjabis or Bengalis. Ien Ang (2005) argues that diasporas are "transnational, spatially, and temporally sprawling socio-cultural formations of people, creating imagined communities whose blurred and fluctuating boundaries are sustained by real and/or symbolic ties to some original "homeland"' (25). Furthermore, diasporas are created through some form of migration, but not all migration involves diasporic consciousness (Vertovec, 2000, 12). Being transnational means belonging to two or more societies at the same time, as in Indian societies (Vertovec, 2005). Thus, transnationalism, in addition to the traditional understanding of cross-border migration, can include citizens migrating across different states in the same country, creating a higher degree of connection between individuals, resulting in changes in the social, cultural, economic, and political landscape of the origin and destination societies. Thus, when people migrate between states, the diaspora functions as transnational (Vertovec, 2005). Nevertheless, migration creates a sense of alienation and displacement that causes an identity dilemma. 
Cultural pluralism also plays an important role in identity formation in people's lives. India is a multidimensional country with different cultures and traditions, religions, languages, and practices. People have crossed borders within the country or subnational or transnational borders in search of a better life, often leaving their homeland (Chang, 2010). Chang argues that borders are not only geographical, but also have cultural, political, and economic effects, which leads the diaspora into a dilemma. In this sense, a person who crosses borders and migrates within Indian jurisdiction becomes not only racially hybrid but also culturally hybrid: "culture and race, which have co-evolved, are intertwined..." (Young, 28). Following cultural paths different from one's own, whether within or across borders, leaves individuals vulnerable to varying degrees of homelessness. Migrants have become exiles in their dislocated lives, resulting in physical or psychological conflict, but they must navigate foreign spaces and struggle with hybridized identities to survive in the new culture. In Edward Said's words, "Borders and barriers, which enclose us within the safety of familiar territory, can also become a prison and are often defended beyond reason or necessity" (Said, 185). Said explains that exile is a complex phenomenon. It is cold, colorless, and bleak. Therefore, the exile character plays a role whether it is an exile in the homeland, an exile outside the homeland, or an exile within the borders of one's own country due to social exclusion. The diasporic characters in the homeland represent marginalized, victimized, exploited people whose voices go suppressed or unheard. Balram and Chuyia, who feel alienated, have no existence or identity of their own and are not represented in their host country. Though marginalized and silenced, we see them debating the discourse of patriarchal domination and striving for freedom. In Kiran Desai's works, such as The Inheritance of Loss, it is easy to sense the feeling of living in exile; the sense of not belonging anywhere, the difficulties in relationships, and the different experiences Indian immigrants have in the United States and England. It also shows how people feel isolated in their motherland and suffers from a loss of identity (Subbulakshmi, 2019). Jasmine in Jasmine, rather than being in exile in India, rebels against the patriarchal society and racial fixation and leaves her motherland for the United States. Exile inevitably shapes and constructs the identity of diasporic characters.

The diasporic experience is best rendered by authors who were themselves members of the diasporic community. Stuart Hall argues that, when an individual straddles the boundaries between two cultures, the task becomes even more problematic and complex, as it is rooted in memory, tradition, and familial expectations (Hall, cited, in Colonial Discourse and Post-Colonial Theory, 1994). A person who has traveled around the world, leaving behind his ancestral homeland and roots, finds himself amid disequilibrium and uncertainty; clear evidence of this can be found in his writings. Vijay Mishra, in a lecture at Victoria University of Wellington, asserts that "diaspora refers to people who do not feel comfortable with their non-hyphenated identities as indicated in their passport" (Mishra, 1). They try to explore the meaning of the hyphen, which has been a symbol of dual identity. Feng points out that the hyphen has often been used to separate identities rather than considering the possibility of a single identity (1996). Therefore, they represent the episteme of displacement and the sense of exile. In The Inheritance of Loss and Jasmine, one can see how closely this hyphenated identity is intertwined. The need to connect with one's origins and yet be part of this new land is important to all the characters in the novels.

All of the characters portrayed in the novels are in some sense in exile in their home country or abroad. While Balram in The White Tiger reinvents his idea of morality by moving away from his village to escape the existing moral virtues and codes of conduct of the patriarchal caste system, Chuyia in Water is labeled as unholy or contaminated due to the social bias and religious hypocrisy in the Indian caste system. Jasmine in Jasmine, rather than staying in exile under the dominant Indian culture, breaks free from the social taboos of the conventional society and chooses to redefine as an immigrant: "Paradoxically, exile to Jasmine is safety; through it, she breaks free from a conventional Indian society" as argued by Fadla, S. \& Awad, Y (2018). Biju in The Inheritance of Loss arrives in America as a stranger, to pursue the American dream, so that he can achieve his version of success, but he spends the rest of his life negotiating the complex dynamics of home and homeland. He suffers moments of doubt and depression and often misses India. The loss and absence of family members evoke in him feelings of exile and loneliness. Jemubhai Popatlal Patel, the Judge, cannot forget his experience of leaving India to London, where he saw "the platform between benches labeled 'Indians Only' and 'Europeans Only"' (Desai, 41), a situation in which he finds himself helpless, and later leads a life of loneliness and alienation. Race, religion, caste system, and social taboos can become an important part of ethnic identity in the process of redefining Indian diasporic identities. Many characters embody a sense of displacement, which represents a deep sense of isolation and a painful inability to communicate one's innermost feelings.

Having examined the concept of displacement and alienation in diaspora discourse from the perspective of ethnic minority heterogeneity, this study aims to ask these questions: Can the experiences of lower caste Indians be considered diasporic within the homeland, and if so, would the experience be the same for Indian women? Can the 
diaspora be doubled with migration? How can the experiences of non-hybrid Indians be interpreted differently from those of people with hyphenated identities? The study provides insights into the experiences of identity dilemma, which allows for the development of a theoretical framework that allows us to rethink these terms: 'alienation,' 'belonging,' 'diaspora,' and 'displacement.'

Thus, the study leads us to a holistic view of 'diaspora' that encompasses a range of displaced existences, whether in India or abroad. Diaspora in the homeland is closely linked to a variety of caste, social and political factors. Chuyia is doubly marginalized: first, because of her gender, and second, as a widow. Balram is stigmatized because they are from marginalized groups and lower classes. They are labeled as "others" by the politics of power dynamics and hegemony exercised and enjoyed by a privileged class. Hall argues that marginalized people who are perceived as "Other" develop a "double consciousness" in the process of cultural hybridization (1996). The migration of diasporic experiences in the West can be classified as a "double diaspora" -a hybrid experience characterized by multiple dualities, being both Indian-American and British, and playing a dual role as a cultural mediator between India, America, and Britain. Whether abroad or at home, diasporic characters undergo the process of alienation both physically and psychologically. As about identity formation in the context of cross-racial and cross-cultural encounters, Homi K. Bhabha theorizes the concept of cultural hybridity in his book The Location of Culture (1994). $\mathrm{He}$ argues that immigrants and other minority groups often feel isolated and alienated or remain in an in-between state, attempting to adapt to new cultures to fit within the boundary of their new identity (54). In this sense, hybrid or non-hybrid individuals are dislocated within or outside of the homeland, whether Indian or hyphenated Non-hybrids feel displaced, isolated, or alienated in their homeland because of the different cultures or caste systems in India, as one caste ultimately out-casts the other. The feeling of displacement occurs when one individual experiences the highest fitness and the other tends to evolve to be less like the other.

The various levels of the Indian diaspora within the homeland and the characters who move to the West are very much the subjects of this study, which is presented in the following four novels: Aravind Adiga's The White Tiger (2008), Bapsi Sidhwa's Water (2006), Kiran Desai's The Inheritance of Loss (2006) and Bharati Mukherjee's Jasmine (1989). The characters who move to the West are doubly alienated and doubly struggled in the diaspora coming from both minority (ethnic or parental) and majority (mainstream or host) cultures. But the new cultural identity also offers something else- it allows for a new interpretation of culture, free of the cultural baggage associated with parental or ethnic identity. However, most of the characters within the homeland are doubly marginalized. These novels discuss identity each from a particular cultural context: the Indian community in the United States, the Brahmins in the Indian caste system, the privileged and less-privileged status of Indian individuals, and the hegemonic aspirations of the middle class that have taken the form of politics and produce socio-cultural inequalities. Due to the complex social structure dominated by the Indian caste system, the study will shed light on two aspects: first, the multi-layered cultural and social constraints that lead to alienation within the boundaries of the homeland. Another aspect to be explored is the migrants' experience of the restrictions imposed by the traditional society to which they belong in their home country, which in turn affects identity formation. Despite their sense of alienation, displacement, and rootlessness, the protagonists in all of the above novels manage to create a space of belonging, whether at home or abroad, despite social, political, and cultural obstacles.

\section{Widows as doubly marginalized in Bapsi Sidhwa's Water}

Bapsi Sidhwa's Water questions the religious tradition and the oppressive constraints imposed on Hindu widows and shows how the characters move towards the construction of the self and forms of coexistence. Set against the backdrop of Gandhi's Freedom Movement, the novel focuses on a group of women condemned by Hindu law to spend the rest of their lives in an ashram, an institution because they are widows. Chuyia, the protagonist, faces double marginalization: first being born a woman and second as a widow. Widows are not allowed to remarry or fall in love because they have to remain chaste. Chuyia's head is shaved after she becomes a widow and is thrown out of her home. According to the Hindu tradition of that time, widows' heads are shaved, and their lives are given over to repentance. Widows have to maintain their chastity, but at the same time, some widows' sexuality is used as a source to satisfy their sexual needs. Religion, then, which plays a dominant role in society, exhibits a clear inclination to privilege transcendence over convergence, and men over women. A widow's sexuality is exploited for the convenience of a patriarchal society. It is quite ironic how widows are considered by Brahmin men as inauspicious and a curse in society, but at the same time, Brahmins enjoy young widows' sexual excess.

\section{Marginalized Balram in Aravind Adiga's The White Tiger}

Aravind Adiga is another diasporic writer, whose novel The White Tiger portrays an Indian society in flux, where various sections of the social order find themselves in multiple cultural encounters. As mentioned earlier, 
cross-cultural experiences generally refer to encounters between different people from different nations, religions, or global regions. India is a land of diverse civilization which consists of many states, cultures, religions, and languages, and therefore there are always cross-cultural experiences. Balram, who is born to a lower-class family, starts his life in "darkness" and then finds his way to the "light" (The White Tiger, 12). Through the protagonist's eye, Balram, the author, portrays two classes of Indian society: the lower class represents "darkness," filled with poverty and a sense of duty to the family; and the higher class represents nepotism, malfeasance, a breeding ground for corruption. Marginalized and doubly alienated like Chuyia, he not only revolts against the patriarchal system of caste hierarchy but also manages to improve his fate by defying all social and economic protocols of India and thus explains what Stuart Hall (1990) means by diasporic experience when he claims that, "The diaspora experience is defined, not by essence or purity but by the recognition of a necessary heterogeneity and diversity, by a conception of 'identity' which lives with and through, not despite, difference; by hybridity" (235). So the question of cultural identity is not 'who are you?' but, 'what can you become?' It does not see the foundation, the essence of your birth, but rather how you position yourself now, as we see in Balram's transformation from a village boy to a chauffeur, and then climbs the social ladder to become a successful businessman.

\section{Widow as a Minority in Mukherjee's Jasmine}

Bharati Mukherjee gives insights into the experiences faced by minority communities in her novel Jasmine. Jasmine was born as Jyoti in a small Punjabi village in a patriarchal society, and giving birth to a girl meant suffering and pain. Being a woman, she experiences identity crises and cultural conflict, both in and out of her own culture. After being widowed, she rebels against patriarchal and racial fixity discourses and travels to the United States alone, where she goes through many tribulations to restore her identity and self. Jasmine transcends the boundaries of ethnicity and nationalism, and in this sense, she is in a double diaspora. To adapt to the American way of life, Jasmine assumes a new identity in different phases of her life: From "Jasmine," to "Jazzy," "Jane" and then "Jase." As F.T. Ruppel puts forward, "she must change to survive and to continue her journey" (Ruppel, 183). She accepts the divergent names and identities in various phases of her life to create a balanced relationship with those identities. This formulates Hall's definition of identity in his essay "Cultural Identity and Diaspora" (1990), where he argues that, "identity is not something that already exists, transcending place, time, history, and culture" (225). Cultural identities undergo a constant transformation, as they cannot be detached from "the different ways we are positioned by, and position ourselves within, the narratives of the past" (Hall, 225). In other words, identity is both consciously constructed and given. Therefore, identity is not a pure, inherent, or wholly transparent human characteristic.

\section{Loss of Identity and self in Kiran Desai's The Inheritance of Loss}

Cultural factors are necessary for the search for identity and self, especially for diasporic immigrants. In Kiran Desai's The Inheritance of Loss, Jemubhai Popatlal Patel, born in India under colonial rule, is sent to London in 1939 at the age of twenty to pursue his Law degree and struggles to adapt to the host culture. Despite the Judge's privileged position in the Indian social hierarchy, he feels inferior when he confronts a white-skinned person. From a colonial perspective, this illustrates the colonial dictates of the colonized and the colonizer, and the Self and the Other. He is marginalized and feels uncomfortable under his colored skin, and tries to mimic the Other, which portrays his inner conflict of resistance against his native Self. This imitation is a means to create the space of escapism, which enables him to disguise his inferior complexes and reflects his double consciousness. After he returns from London, he imitates the manner and culture of Europe and behaves like British. He seems to be caught between the past and the present, between his days in a foreign country, and his ordinary life in Kalimpong, North East India. This makes him look ridiculous and is not accepted by the Indians, which leaves him isolated and alienated. Biju, the son of the cook, is another important character, who is sent to the US to fulfill his American dream. He is racially discriminated against and experiences utter loneliness. Being an illegal immigrant, he fails to assimilate into western society, which reflects his identity dilemma. Almost all the diasporic characters are caught between two conflicting cultures, with their highly distinct social and ideological differences. As Brah argues, "Diaspora often invokes the imagery of traumas of separation and dislocation, and this is certainly a crucial aspect of the migratory experience" (190). Brah further argues that "the concept of diaspora refers to multi-locationality within and across territorial, cultural and psychic boundaries" (194). They perceive a sense of living in exile, loss of communication, and a sense of belonging to nowhere. They are doubly alienated and displaced, both psychologically and physically. Jemubhai has lost almost everything and his identity, and Biju suffers embittered feelings of loss during his stay in America. Like Jasmine, they also became members of the double diaspora. Their post-traumatic stress leads to complicated issues of hybrid identity. As Hall states in his essay, identity is both "a matter of 'becoming' and of 'being"' $(1990,225)$. In this sense, some differences add up to "what we are and 'what we have become.' It is an interaction between the individual and the social contexts we live in, which is impacted by forces Published by Sciedu Press 
such as race, class, politics, religion, language, gender, and changes.

In almost all of the novels examined, this study argues that caste is very much active, as is post-colonialism, and social hierarchy is still a stigma in Indian society. Indians from lower castes experience alienation in the diaspora as described by Diasporas. Their diasporic experiences may have been projected within the same nation and doubled either under patriarchy or across nations. The characters who end up in the West are doubly alienated and doubly struggled in the diaspora. They assert their claim to American and British identity as they struggle to successfully re-establish themselves in a new cultural landscape. Yet, almost all of the characters gain a sense of self-identity and self-worth in their quest for freedom. All of the characters feel alienated on their life journey, which is an essential part of identity formation, but they learn to face the pain with courage. All of the novels, then, deal with themes of identity and displacement, whether outside or inside India. However, the issue of double diaspora and how identity is particularly challenged in the discourse of minorities occupying the space of the nation is interesting and worth exploring.

The study is an attempt to examine identity dilemmas and conflicts of cultural value reflected in the characters at home and abroad portrayed in Indian literature. The study aims to portray different levels of diaspora. The characters in the homeland remain displaced, uprooted, and have no distinct place to call 'home'. Their home refers to the feeling of exile, as they have experienced exclusion by the locals. The characters in the West are caught between two worlds with an ever-increasing multiplicity of identities, whose cultural isolation leads to personal dilemmas. All the novels in my study deal with the problem of alienation, exile, and displacement against the backdrop of Indian social practices.

The study represents diasporas within and outside the homeland. The complex stratification systems in India result in a variety of social categories and gender differences. Caste as a system and ideology contributes to the multiple marginalization and oppression of lower castes. Women are doubly marginalized, like Chuyia: first as a woman and then as a widow. Without any social infrastructure or financial security, many are abandoned in Ashrams, where they live on handouts while waiting to die. Jasmine, who experiences a double diaspora, is also marginalized as a woman in India, but she challenges and breaks society's patriarchal norms by immigrating to the United States all by herself. Jemubhai Patel and Biju, are torn between the two cultures which emphasize the psychological displacement of the doubly alienated diaspora in the U.K and the US. Gender inequality is based not only on biology but also on social stratification. Men from the lower caste are discriminated against and dehumanized. While Chuyia is ostracized by other members of the community because she is a widow, Balram rebels against the patriarchal hierarchy and kills his employer because it allows him to break the cycle of poverty. This means that the power play of patriarchy permeates every aspect of Indian society, and leads to a variety of discriminatory practices. Therefore, this paper explores different ways in which the caste system affects Indians in specific situations: social, gender, and political situations.

In conclusion, I would surmise that people engage in a variety of intertextual identification processes to maintain a sense of "self" and "other" in social interactions. By following such rituals, they can build their identity as a person and simultaneously build their public identity as a social actor. Because such behaviors articulate the person about the social, "identification," and can be understood as a fundamental bridging concept between the individual and society. The article examines how characters in the Indian novels under consideration express themselves to each other and themselves, and how various interactions can demonstrate how individual actors experience, affect, reconstruct, and are subject to the situational and structured "realities" they inhabit.

The theme of exile and alienation is almost poignant in all four novels, and the novelists express the oppressive nature of the power structure through the lives of the diasporic characters. Although the characters are recognized as Indian minorities; they nevertheless, occupy a contested position within the discourse of Indian national identity and yearn for identity, acceptance, and love. All the characters from the diaspora are victims of dilemmas due to the unhappiness they experience in their home countries and abroad. Although India is their birthplace and the realm of their experience is historical memory, "home," both as a physical and psychological space, justifies its status as a contradictory site of resistance and confinement. According to Thembisa Waetjen's article "The 'Home' In Homeland" (1999), "Unhomeliness" is not explicitly a state of homelessness, but rather a state of exile, of being removed from a place of belonging (662). Lois Tyson describes "unhomeliness" as the sense of displacement and fragmentation felt by a colonized subject (Tyson, 421). This leads to the need for different diasporic characters to develop a new sense of identity in their home country and abroad.

The diaspora at home, Chuyia in Water, depicts the postcolonial people's struggle for survival against superstition. The only hope lies in Gandhi's words, which gave them a dream and faith that one-day society would stop alienating 
and mistreating the lower caste people. On the other hand, Balram Halwai in The White Tiger, who is a victim of systemic inequality in India, rebels against the class hierarchy of the social structure and climbs the ladder to success.

Moreover, the gender issue regarding Third World women coincides with Spivak's theory that Indian women are often discriminated against based on ethnicity, gender, and class. Women have remained on the periphery, exemplified by Jasmine, the widow in Jasmine. However, Jasmine rebels and transforms into an American lady by "becoming rooted" (Mukherjee, 179).

Moreover, uprooting from one's country and returning to a foreign land is a painful process. However, Jasmine in Jasmine frees herself from the comparative "solidity" offered by her homeland and tries to adapt to the dominant white culture through her transition and transformation from an Indian living abroad to an American. On the other hand, a pessimistic tone prevails in The Inheritance of Loss. Characters such as Jemubhai and Biju are torn between two worlds by the collision of East and West and struggle to find their belonging and identity in both worlds. Gyan struggles against the adversities of foreign cultures to protect his traditional identity.

Thus, we have seen that the constant rejection and degradation of people causes the characters to be marginalized and unable to feel a sense of belonging, leading them into an identity dilemma. In this paper, I have tried to show how cultural encounters lead diasporic characters into a tangle of identity crises and how different diasporas raise issues of alienation in different spheres of life in their home countries and abroad.

In short, the paper explores the various ways in which the caste system affects Indians at home and beyond. It demonstrates how the diaspora at home can be viewed without immigration and how diasporic characters abroad are part of the dual diaspora. Based on these four novels, the conclusion presents the results of the discussions on diasporic individuals, individuals who are part of the dual diaspora abroad, and minority characters in the home country who are stigmatized. The different results reflect the differences between the characters in each chapter.

\section{References}

Adiga, A. (2008). The White Tiger. London: Atlantic-Grove Atlantic.

Agarwal, M. (2009). English literature: Voices of Indian diaspora. New Delhi: Atlantic Publishers \& Distributors.

Anand, M. R. (1935). Untouchable. London: Penguins Books.

Anderson, B. R. O. G. (2006). Imagined communities: Reflections on the Origin and Spread of Nationalism. London: Verso.

Ang, I. (1994). On not speaking Chinese: Postmodern ethnicity and the politics of Diaspora. New Formations: A Journal of Culture/Theory/Politics, 24(Winter), 1-18.

Ang, I. (2005). On Not Speaking Chinese: Living Between Asia and the West. Milton: Taylor \& Francis. https://doi.org/10.4324/9780203996492

Bhabha, H. K. (1994). The Location of Culture. London; New York: Routledge.

Brah, A. (1996). Cartographies of Diaspora: Contesting Identities (1st ed.). Routledge. https://doi.org/10.4324/9780203974919

Chang, B. (2010). The power of geographical boundaries: Cultural, political, and economic border effects in a unitary nation. Iowa State University, Digital Repository, Ames.

Clifford, J. (1994). Diasporas. Cultural Anthropology, 9(3), 302-338. https://doi.org/10.1525/can.1994.9.3.02a00040

Cohen, R. (1997a). Global Diaspora: An Introduction. London: UCL Press.

Desai, K. (2007). The inheritance of Loss. Open Road+ Grove/Atlantic.

Dhakal, Lekha N. (2016). Subaltern consciousness in Aravind Adiga's The White Tiger'. International Journal of English Language, Literature, 3(4), 111-124.

Du Bois, W. E. B. (1903). The Souls of Black Folk. New York: Dover Publications.

Du Bois, W. E. B. (1996). The Souls of Black Folks. In Eric J. Sundquist (Ed.), The Oxford W.E.B. Du Bois Reader, pp. 97-240. New York: Oxford University Press.

Feng, P. (1996). Being Chinese American, Becoming Asian American: "Chan Is Missing." Cinema Journal, 35(4), 88-118. https://doi.org/10.2307/1225719

Geethanjali, N., \& Jayalakshmi, S. (2017). Post-Colonial Perspectives in Bapsi Sidhwa's Water. English: Literature and Social Issues, 17(3), 11-17. 
Gilroy, P. (1994). Diaspora. Paragraph, 17(3), 207-212. https://doi.org/10.3366/para.1994.17.3.207

Goyal, S. (2017). The saga of the journey of the Indian diaspora. Smart Moves Journal IJELLH, 5(6), 14. https://ijellh.com/OJS/index.php/OJS/article/view/2068.

Hall, S. (1990). Cultural Identity and Diaspora. In J. Rutherford (ed.), Identity: Community, Culture, Difference, pp. 222-237. London: Lawrence and Wishart.

Hall, S. (1994). Cultural identity and diaspora. In (Eds.), P. Williams \& L. Chrisman. Colonial discourse and post-colonial theory: a reader, pp. 392-401. London: Harvester Wheatsheaf.

Hall, S. (1996). Negotiating Caribbean Identities. New Left Review, 209, 3-14

Knott. K., \& McLoughlin, S. (2010). Introduction. In K. Knott \& S. McLoughlin (Eds.), Diasporas: concepts, intersections, identities, pp. 1-16. London; New York: Zed Books. https://doi.org/10.5040/9781350219595.0005

Kroeber, A. L. (1930). Caste in Encyclopedia of the Social Sciences, 3, 254-57. New York: Macmillan.

Mishra, V. (2005). The diasporic imaginary and the Indian diaspora. Asian Studies Institute. Occasional lecture 2. Victoria University of Wellington, 29 August 2005. Retrieved from http://hdl.handle.net/10063/4255

Mukherjee, B. (1990). Jasmine, Penguin Books (India), New Delhi.

Reddy, M. (2015). Transnational locality: Diasporas and indentured South Asians, Diaspora Studies, 8(1), 1-17. https://doi.org/10.1080/09739572.2014.957977

Ruppel, F. T. (1995). Re-Inventing Ourselves a Million Times: Narrative, Desire, Identity, and Bharati Mukherjee's Jasmine. College Literature, 22(1), 181-191.

Safran, W. (1991). Diasporas in Modern Societies: Myths of Homeland and Return. Diaspora: A Journal of Transnational Studies 1(1), 83-99. https://doi.org/10.1353/dsp.1991.0004

Said, E. W. (2000). Reflections on Exile and Other Essays. Harvard: HUP. Print.

Sharma, A. (2018). Victimization of Women: With particular reference to Bapsi Sidhwa's novels. International Journal of Research and Analytical Reviews, 5(4), 464-468.

Sheffer, G. (2003). Diaspora Politics: At Home Abroad. Cambridge University Press, UK. https://doi.org/10.1017/CBO9780511499432

Sidhwa, B. (2006). Water. New York: Oxford University Press.

Subbulakshmi, A. (2019). Identity crisis in Kiran Desai's The Inheritance of Loss. Journal of English Language Teaching and Literary Studies, 7(1), 7.

Tiwari, K. L. (2013). Identity Crisis-Indian English fiction of post-1980s. International Journal of English and literature, 4(1), 6-10. Retrieved from http://www.academicjournals.org/ijel

Tyagi, M. (2017). Theory of Indian Diaspora: Dynamics of Global Migration. Horizon Books.

Tyson, L. (2014). Critical Theory Today: A User-Friendly Guide. Routledge. https://doi.org/10.4324/9781315760797

Vertovec, S. (2000). The Hindu Diaspora: Comparative Patterns. Psychology Press.

Vertovec, S. (2005). The Political Importance of Diasporas. Working Paper No. 13, Centre on Migration, Policy, and Society, University of Oxford.

Waetjen, T. (1999). The "home" in the homeland: gender, national space, and Inkatha's politics of ethnicity. Ethnic and Racial Studies, 22(4), 653-678. https://doi.org/10.1080/014198799329332

Werbner, P. (2010). Complex diasporas, pp. 74-78. In K. Knott and S. McLoughlin (Eds.), Diasporas: Concepts, intersections, identities. London: Zed Books. https://doi.org/10.5040/9781350219595.ch-012

Young, R. J. (2005). Colonial Desire: Hybridity in Theory, Culture, and Race. New York: Routledge. https://doi.org/10.4324/9780203992203

\section{Copyrights}

Copyright for this article is retained by the author(s), with first publication rights granted to the journal.

This is an open-access article distributed under the terms and conditions of the Creative Commons Attribution license (http://creativecommons.org/licenses/by/4.0/). 